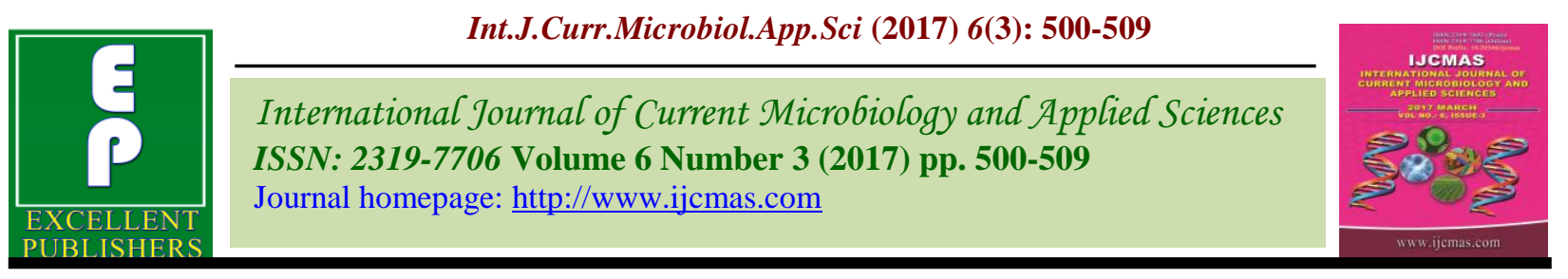

Review Article

https://doi.org/10.20546/ijcmas.2017.603.058

\title{
Source-Sink Relationship in Litchi verses Mango: A Concept
}

\author{
Sanjay Kumar Singh*, Vishal Nath, E.S. Marboh and Swati Sharma \\ ICAR-National Research Centre on Litchi, Mushahari Farm, Muzaffarpur, 842 002, Bihar, India \\ *Corresponding author
}

\section{A B S T R A C T}

\begin{tabular}{|l|}
\hline K e y w o r d s \\
Carbohydrates, \\
$\begin{array}{l}\text { Flushing, Girdling, } \\
\text { Photo-assimilate, } \\
\text { Source, Sink. }\end{array}$ \\
\hline Article Info \\
\hline $\begin{array}{l}\text { Accepted: } \\
\text { 10 February } 2017 \\
\text { Available Online: } \\
\text { 10 March } 2017\end{array}$ \\
\hline \hline
\end{tabular}

In fruit production, the effects of flowering and fruiting, which modify source-sink relationships, cannot be overlooked and is even more true in tropical fruit production, where the flowering and fruiting phases exceed six months at the individual tree scale. More specifically, little is known about the effects of source/sink balance, and the associated changes in carbon export rate from leaves and leaf carbohydrate concentration, like the ones resulting from the presence of developing fruits, on leaf nitrogen and photosynthetic capacity within the crown of field-growing trees. The amount of carbohydrates supplied to tree fruits depends on the amount produced by leaf photosynthesis, on sink demand and on the availability of the reserve pool. Also, from the point of view of fruit quality, it is essential to understand how pre-harvest factors influence source-sink relationships involved in fruit growth. The intra-plant variation in flushing and shoot growth pattern influences the overall floriferousness of the litchi plants. The inability of shoots emerging after harvest from the fruiting terminals to bear fruits in the next spring was probably due to depletion of food reserves in the supporting tissues as a result of which the new shoots could not mature enough in time to differentiate to flower buds for the next crop. The major role of translocated assimilates from other plant parts in fulfilling the assimilate fruits in litchi where current photosynthesis contributes partially towards assimilate demand. The mango fruit size increased with increasing leaf-to-fruit ratio. In addition, to produce larger fruit at harvest on branches with the highest leaf-to-fruit ratio, changing carbohydrate supply to the fruit increased the proportion of fresh mass in the flesh to the rest of the fruit.

\section{Introduction}

Fruit trees exhibit two major multiannual reproductive strategies (Goldschmidt, 2013). First the regular bearer one, the amount of fruit produced allows a sufficient amount of vegetative growth to support production of an ample number of flowers during the following year (return bloom). They are characterized by a relatively stable multiannual yield, and usually possess efficient mechanism(s) to control excess fruit production. In the biennial bearer ones, that bears a heavy fruit load (ON-
Crop) in one year, which inhibits return bloom and vegetative growth the next year (Monselise and Goldschmidt, 1982) i.e. second year is characterized by low yield (OFF-Crop) and high vegetative growth and they are usually characterized by low selfthinning ability (Goldschmidt, 2013).

Alternate bearer cultivars present a serious economic problem to fruit growers. Therefore, proper canopy management is 
required or chemical or manual branch or fruit thinning are common practices through which heavy crop load affects return bloom can be managed. The developing fruit provides a strong sink for photo assimilates. It was therefore thought that depletion of photoassimilates, especially carbohydrates from the bud, prevents flowering induction, a hypothesis known as the nutritional theory (Goldschmidt, 1999). Plant performance i.e. how does a plant grow under various conditions depends on the acquisition of raw material (carbon fixation and mineral uptake), the allocation of this material over the plant organs, and the ability to cope with environmental stresses.

Modern fruit growers try to manipulate the source-sink relationship to guarantee adequate fruit production with quality. Balance maintenance between vegetative and generative growth of a tree is of great importance for growth and production of fruit plants (Park, 2011). Producing and exporting organs in the plant (typically mature leaves) are known as sources, while nonphotosynthetic organs (fruits, roots and tubers) and immature leaves are known as sinks (Taiz and Zeiger, 2006). Marschner (2012) pointed out that the source (supply of photosynthates) - sink (utilization of photosynthates) limitations are strongly affected by interactions between genotype and environment. The relationship between photosynthetic and non-photosynthetic tissues is less pronounced in fruit trees than in herbaceous plants due to the structure of the tree, which implies high energy costs to maintain a notable quantity of nonphotosynthetic tissue.

A sink hierarchy is usually considered among organs or tissues of perennial species and summarized by the following priority rank ordering from high to low i.e. seeds > fleshy fruit part >shoot apices > mature leaves $>$ cambium >roots > storage (Lauri et al.,
2010). The overlap in time between primary growth (encompassing shoot extension and fruit growth), and secondary growth plays an important role in shaping these allometric relationships.

\section{Source-sink relation}

The term source-sink relationship refers to the integration of sugar and amino acid production in photosynthesis with sugar and amino acid utilization in growth, storage, maintenance and production (Foyer and Paul, 2001). Within a plant, the "source" can be defined as a photosynthesizing tissue or organ with substantial Rubisco activity and export of carbon skeletons and typically comprise all types of green leaves, once they become carbon-autonomous or autotrophic. Within a plant, a "sink" could be defined as a heterotrophic tissue or organ which

- Requires import of carbon or/and nitrogen compounds, and/or

- Shows respiration viz respiratory $\mathrm{CO}_{2}$ efflux exceeding $\mathrm{CO}_{2}$ assimilation

- Large activity of an auxin-type plant growth regulator such as IAA

- PEPC (phosphoenol pyruvate carboxylase) activity exceeds Rubisco enzyme activity

Typical examples for "sinks" are flowers, petals, fruits, shoots or roots; the role of any of these organs may change once and irreversibly during ontogeny from "sink" to "source" over time with the sink hierarchy in plants i.e. Fruit $>>$ flower $>>$ root $>$ shoot $>$ leaf (Blanke, 2009). Initial sinks like developing leaves or shoots may undergo this transition and become carbon sources after leaf emergence. Likewise, the root becomes the predominant sink after harvest viz. fruit removal. "Sink strength" is the ability of a tissue or an organ to mobilize photoassimilates towards itself and may measured as 
- Magnitude of imported carbon or nitrogen skeletons

- Dry matter increment or energy equivalent, starch storage of the xylem parenchyma cells

- Magnitude of auxin synthesis or exported (basipetal) auxin

- Larger PEPC than Rubisco enzyme activity or protein

The "sink capacity" may be defined as the capacity of a tissue or organ to import and store further compounds from the source(s), while the "sink activity" may be defined by the rate of respiration. Under 'fruit photosynthesis' the shoots or fruits contain chlorophyll, to a lesser extent than leaves (do), but do not export carbon skeletons and respire more $\mathrm{CO}_{2}$ than they assimilate, and its biochemical pathways including refixation of (respiratory) $\mathrm{CO}_{2}$ with PEPC as the primary $\mathrm{CO}_{2}$ fixing enzyme (Blanke and Lenz, 1989) to distinguish it from 'leaf photosynthesis' with Rubisco as primary $\mathrm{CO}_{2}$ fixing enzyme.

\section{Competitive carbohydrate economy amongst organs}

Fruit production and quality depend on adequate source-sink relationships. Carbohydrates $(\mathrm{CH})$ translocated from leaves or reserve organs are the most important for the growth and development of sink organs (mainly fruits) (Fig.1b). Up to $60 \%$ of $\mathrm{CH}$ produced daily can be lost through respiration. Carbohydrates constitute over $65 \%$ of the dry matter of tree crops. Increasing the leaf-fruit ratio generally increases fruit growth and $\mathrm{CH}$ content. Photosynthesis increases with fruit load and the leaves next to fruits are strong sources for $\mathrm{CH}$. The leaf-fruit ratio is species, cultivar and geographic location dependent. The optimal leaf area in various species is 200 $\mathrm{cm}^{2}$ per $100 \mathrm{~g}$ of fruit (Fischer et al., 2012).The relationships between sources of assimilates and metabolic sinks are a function of the carbon assimilation capacity of source organs, growth rate and size of the sink, and transport between the two.

Different tree organs compete for $\mathrm{CH}$, which are mainly produced by leaves. Fruits have greater sink strength than other organs. Sink strength in plants without fruits occur in the stem or roots which predominantly attract $\mathrm{CH}$. The upper expanded leaves export $\mathrm{CH}$ to young leaves (even importing) and cauline meristem, as the number of leaves increases, the basal leaves send photosynthates predominantly to the roots (Taiz and Zeiger, 2006). The rate of translocation of photosynthates from the sources (mainly leaves) to the sinks (mainly fruits) influences photosynthesis. The photosynthesis is instantly dependent on leaf export function and disturbance of sink-source relationships is usually created by removing a part of sources or sinks (Fig. 2a). However, reduction in amount of sources do not always lead to increase in photosynthesis and removing a part of sinks do not always result in decrease of photosynthesis (Chikov et al., 2009).

Fruits closer to the main stem have a tendency to become larger because they better compete for $\mathrm{CH}$, and the farthest from the main stem become smaller because they have less of a chance to compete. The exceptions are the fruit produced in the periphery of the canopy which take advantage of direct sunlight, both on the fruits and the adjacent leaves, as compared to those growing under the canopy (Kozlowski and Pallardy, 1997). The degree of competition among various sinks depends on the organ activity and distance from the $\mathrm{CH}$ source.

\section{Training, pruning and girdling}

Each training system plays an important role in light interception and its distribution within 
the tree canopy. Maximum potential assimilation is realized by a canopy that absorbs all incoming light. The removal of leaf area may lead to the compensation of photosynthetic activity of the remaining leaf area at least up to a certain threshold (Layne and Flore, 1992). The fruit size could have been increased by tipping but with this technique the reduction of sinks is correlated with a reduction in carbon sources. There is chronological relationship between flowering period and fruit maturity (delayed flowering leads to a delayed harvest time) and first vegetative activity, flowering and harvest (early vegetative shoot leads to early flowering leading itself to early harvest time) (Jannoyer and Lauri, 2009). Training and pruning alters the balance between vegetative growth and reproductive fruiting by the allocation of resources, such as carbohydrates, water and growth regulators (Myers, 2003) (Table 1). Heavy pruning diminishes leaf area, whole tree photosynthesis and translocation of photosynthates to fruits and roots, increasing the root/shoot ratio and favoring vegetative growth. Food reserves in mango trees may be reduced after hard pruning and this will result in poor flowering in that year. Paclobutrazol helps in accumulation of $\mathrm{CH}$ and this low gibberellins content and high $\mathrm{CH}$ accumulation in the tissues creates a favourable condition for flowering. It is suggested that paclobutrazol should be applied after one of two growth flushers after pruning, when more leaves are present. Paclobutrazol at the rate of $1 \mathrm{~g} / \mathrm{meter}$ canopy diameter drastically reduced $\mathrm{GA}_{3}$ level in mango shoots a month after application. The low GA levels in the shoots brought about by paclobutrazol resulted in the accumulation of total non-structural carbohydrates, primarily starch, in the leaves and buds. These series of events eventually led to the formation of floral initials (Protacio et al., 2009).
In litchi, the warmer the climate the more vigorous tree growth. In general, for terminally bearing species, pruning of large diameter stems/wood results in excessive and/or continuous vegetative flushing. The wider the spacing the longer it takes to require regular pruning. The closer the plant spacing the earlier a pruning program is required and the more frequently trees are pruned. Designing a pruning program for cultivars with a vigorous, upright growth habit is more difficult than for less vigorous, spreading growth habit cultivars.

Girdling (the removal of a ring of phloem) is a common horticultural practice used to manipulate tree growth and development, and fruit growth, in a variety of fruit species. Its most immediate effect is to stop the basipetal movement of assimilates through the phloem, which results in an accumulation of carbohydrates above the girdle.

Girdling has been suggested as a way to promote floral induction in mango, but it has also been shown that it reduces net photosynthesis (Anet) in many species. Being a terminal bearing crop, girdling helps in limiting the carbohydrate source of the growing fruits within the region between the girdled portion and the panicle (Das et al., 2011). Closed girdling, spiral girdling led to increase in flowering in litchi with increases in soluble sugars and starch content in the shoot.

Our results show that girdling may improve earliness of flowering, but at the expanse of carbon acquisition. Although the negative effect of girdling on Anet is reversible, and girdling of small branches has probably exacerbated the rate and magnitude of carbohydrate accumulation and photosynthesis reduction, our results urge us to evaluate the effect of girdling on flowering in the light of its negative side-effect on photosynthesis. 


\section{Phloem unloading and sink utilisation}

The fruiting has strong effects on individual tree growth and architecture: (1) fruit load modifies the partitioning of available carbohydrates and water economy in a short term, (i.e., during annual cycle), and (2) heavy yields affect tree vigor in a longer term by reducing cumulated growth over years. Reaching equilibrium between both growth and fruiting is thus one of the main objectives of the fruit grower. Some cultural practices, by manipulating either source size or sink size, influence source-sink relationships involved in fruit growth. Thinning, which controls crop load by removing the smallest fruits, usually increases the size of the remaining fruit (Goffinet et al., 1995).

Photo-assimilate removal from phloem and delivery to recipient sink cells (phloem unloading) is the final step in photo assimilate transport from source to sink. Within sink cells, cellular metabolism and compartmentation are the end-users of phloemimported photoassimilates. Combined activities of these sink-located transport and transfer events determine the pattern of photoassimilate partitioning between competing sinks and hence contribute to crop yield.

Phloem unloading describes transport events responsible for assimilate movement from secc complexes to recipient sink cells. A distinction must be made between transport across the se-cc complex boundary and subsequent movement to recipient sink cells. The former transport event is termed sieve element unloading and the latter post-sieve element transport. On reaching the cytoplasm of recipient sink cells, imported photo assimilates can enter metabolic pathways or be compartmented into organelles (e.g. amyloplasts, protein bodies and vacuoles). Metabolic fates for photo assimilates include catabolism in respiratory pathways, biosynthesis (maintenance and growth) and storage as macromolecules (starch and fructans). Compared with phloem loading, phloem unloading and subsequent sink utilisation of imported photoassimilates operates within a much broader range of configurations:

1) Morphological (e.g. apices, stems, roots, vegetative storage organs, reproductive organs);

2) Anatomical (e.g. pro-vascular differentiating sieve elements, protophloem sieve elements lacking companion cells, meta phloem se-cc complexes);

3) Developmental (e.g. cell division, cell expansion);

4) Metabolic (e.g. storage of soluble compounds/polymers, growth sinks).

\section{Phenology of litchi verses mango}

Phenology is "the science dealing with the influence of climate on the recurrence of such annual phenomena of animal and plant life as bird migrations and budding"

The growth of the lychee tree is rhythmic, meaning that "the shoots have a marked endogenous periodicity of extension." The litchi being a terminal growing crop, girdling helps in limiting the carbohydrate source of the growing fruits within the region between the girdled portion and the panicle. Furthermore, after leaf removal, plants may compensate for loss of tissue by a number of mechanisms which include morphological and physiological components, such as increased photosynthetic rates and mobilization of storage reserves (Rosenthal and Kotanen, 1994). Periods of extension growth or flushes alternate with periods during which new leaf primordia are initiated from the apical dome, but without shoot elongation. Once a year, during cool weather 
(temperature at $15{ }^{0} \mathrm{C}$ for 15 days), inflorescence primordia are initiated at the apical domes of the terminal buds (Robbetse et al., 1995). The bearing shoot of litchi comprised of three to four flushes and its carbohydrate reserves are essential for adequate cluster production. The age of the vegetative flush, or the degree of dormancy (during cool winter), appears to have a strong influence on the subsequent shoot development. Flush growth should be restricted to $0.6-2.0 \mathrm{~cm}$ in OctoberNovember and that leaves should be removed from flush growth if $>10 \mathrm{~cm}$. These practices prevent alternate fruit set and stabilise yield (Fig. 2).

Table.1 Sink (fruit load) effects on the source and their regulation of carbon and water relations

(Blanke, 2009)

\begin{tabular}{|l|l|}
\hline Fruit/sinks increase & Sinks/fruit reduce \\
\hline Increased stomatal conductance & Reduced stomatal resistance of the leaf \\
\hline Increased transpiration & Reduced leaf ABA content and synthesis \\
\hline Increased water uptake & Reduced water use efficiency (wue) \\
\hline Increased transpiration coefficient & Reduced starch accumulation in the leaf \\
\hline Increase leaf photosynthesis & Reduced shoot and root growth \\
\hline Increase carbohydrate export & Reduced root respiration \\
\hline Increase dark respiration & $\begin{array}{l}\text { Reduced /retarded translocation of carbohydrates and nutrients from } \\
\text { the leaf to the root }\end{array}$ \\
\hline
\end{tabular}

Fig.1 (a) Schematic illustration of factors affecting net photosynthesis and photosynthate translocation and (b) carbon economy in fruit trees (Fisher et al., 2012)

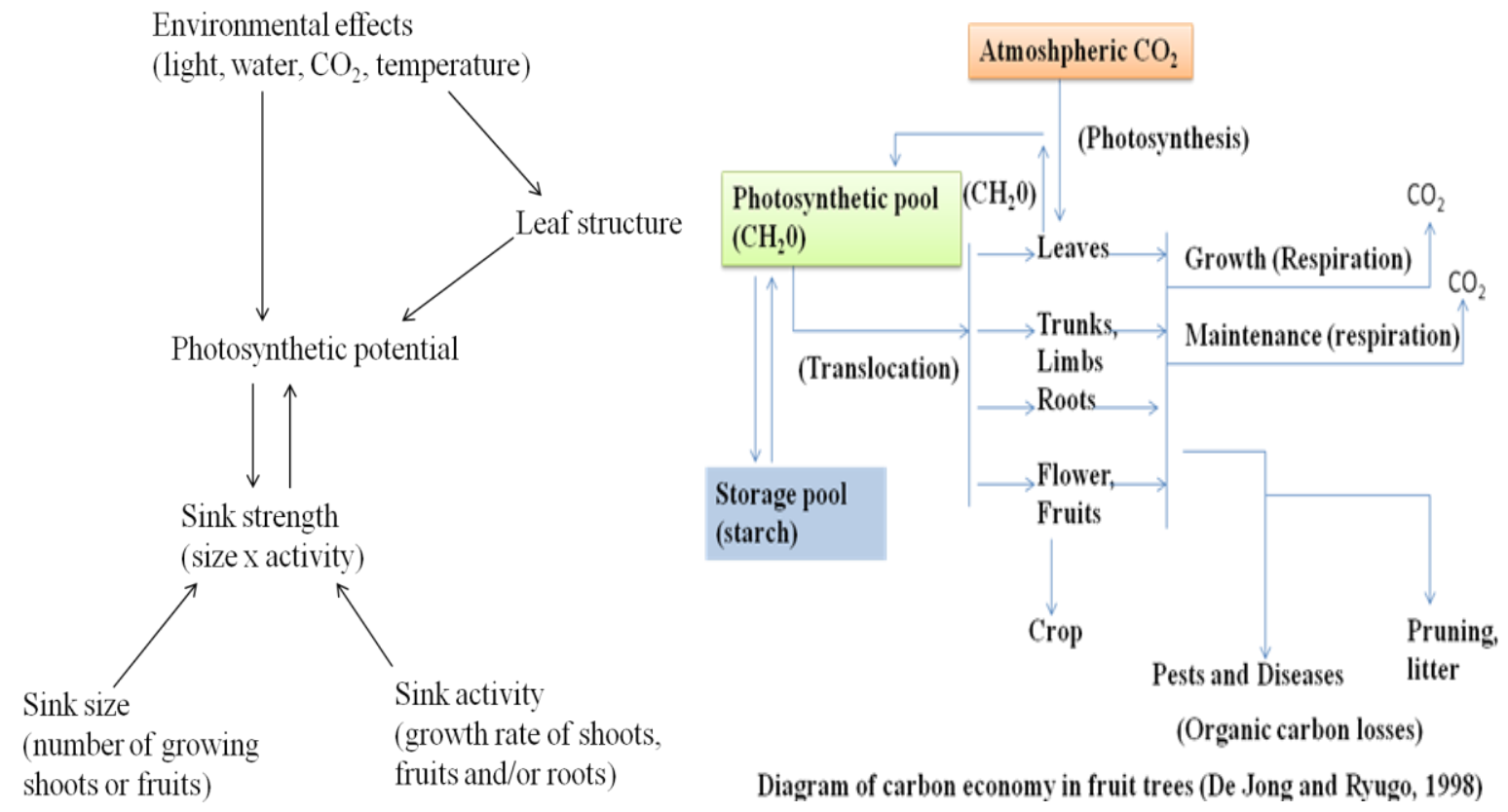


Fig.2 (a) A bearing shoot of litchi with fruit cluster consisted of three mature flushes that had been produced in succession between harvest and quiescence in the previous year; (b) pressure gradient of source and sink

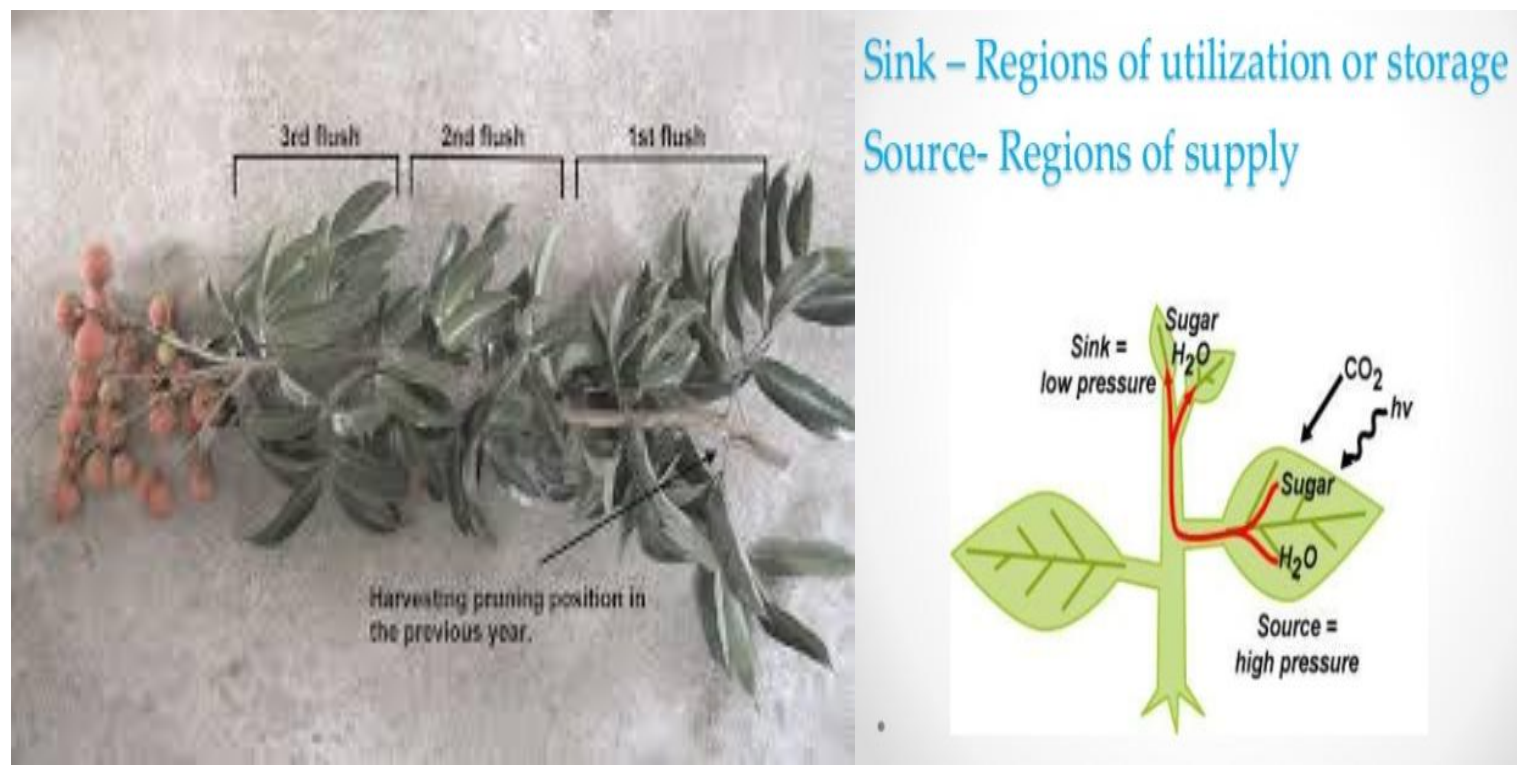

Fig.3 Growth cycle and factors affecting flowering in litchi
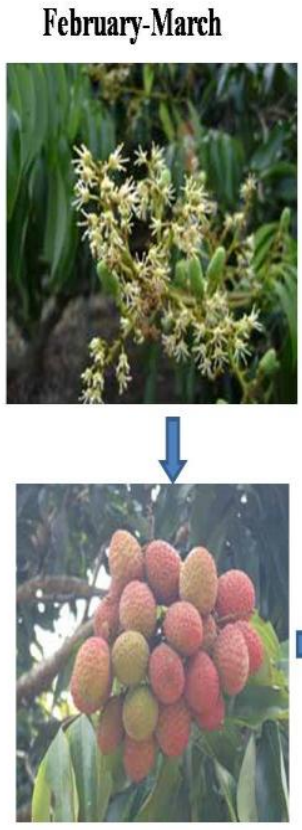

May - June

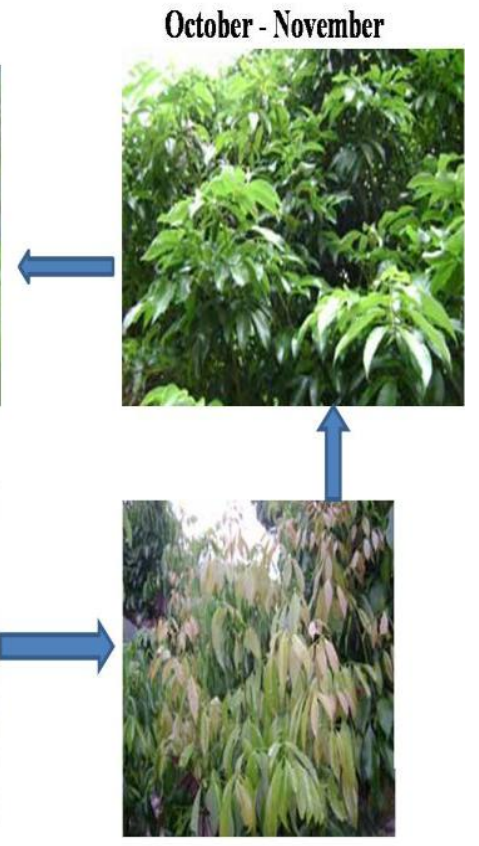

July - August

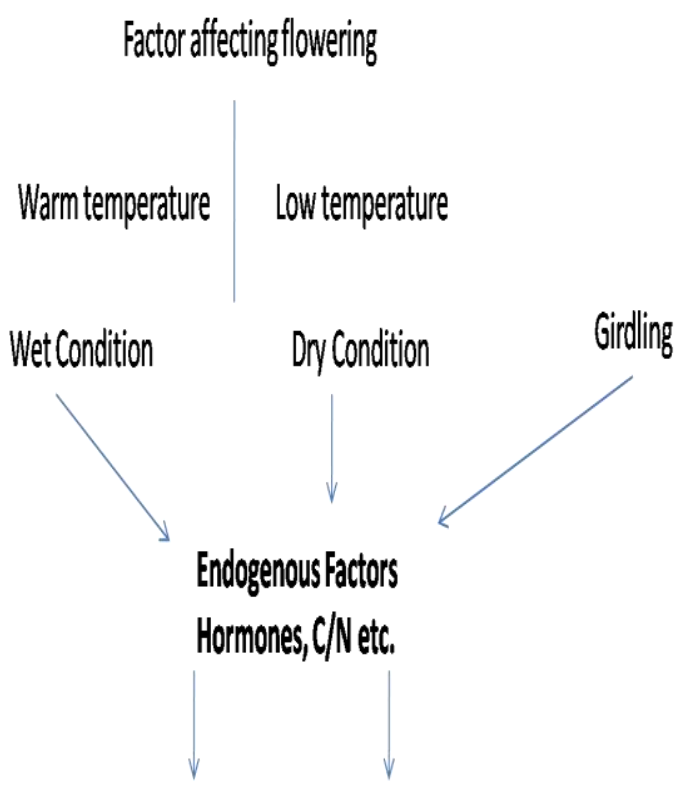

VegetativeGrowth
Reproductive Growth 


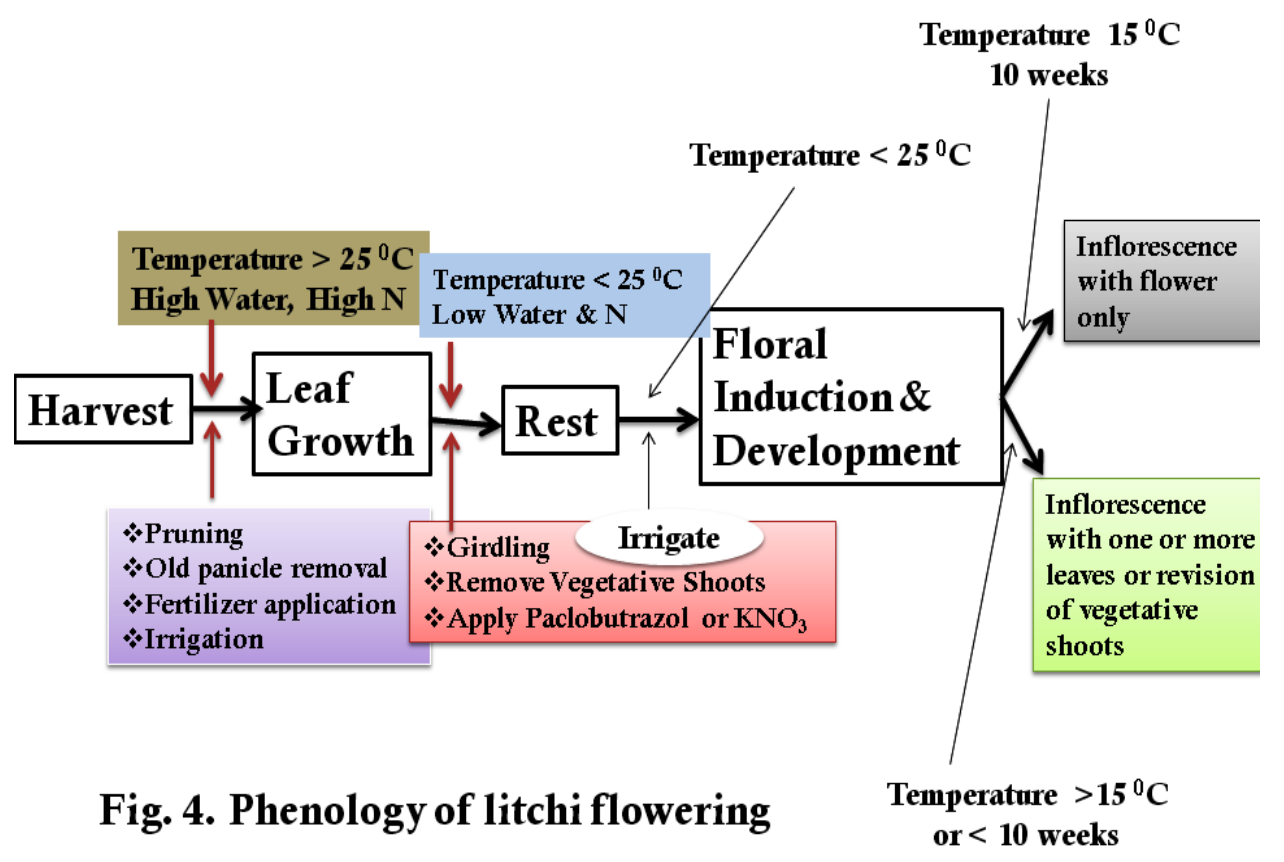

The litchi fruits are born on terminal shoots, with the new leaves and stems growing in a series of flushes (about six to eight leaves), with dormant periods between successive flushes. The bearing shoot of litchi is the major source of carbohydrates for fruit growth, mainly through leaf $\mathrm{CO}_{2}$ assimilation, but also through its carbohydrate reserves when needed (Chang and Lin, 2008). Mango trees grow synchronously throughout the canopy and pass through distinctive stages in subtropical environments. Though resting buds usually break to form vegetative shoots during warm temperatures, a coincidental period of water stress can delay bud break in spite of the warm temperatures until the summer rains arrive. The vegetative shoot growth are: vegetative bud emergence and development stage, elongating green leaf stage, limp red leaf stage (LRL), immature green leaf stage, and mature green leaf stage. Reproductive growth stages in purely flowering, or generative, shoots are: floral bud initiation, emergence and development stage, early panicle elongation stage, mid-size panicle early anthesis stage, and full-size panicle maximum anthesis stage (Ramirez et al., 2014).
Growers can rely on a number of methods which directly or indirectly influence photosynthesis and sink activity (fruit growth). Among these, the most important are tree height, distance, and fruit thinning, pruning, and fertilization, application of growth regulators, irrigation and phytosanitary control (Flore and Lakso, 1989). Girdling (branch ringing), the removal of a bark ring in the trunk or in the base of lateral growth axes, interrupts photosynthate flow to the roots and thereby increases flower induction and fruit filling, apparently through increased sugar availability in the aerial parts of the tree (Iglesias et al., 2007).

The litchi fruit set is strongly dependent on current photosynthesis (Yuan and Huang, 1988). Girdling (a ring of bark and cambium was removed from the branch base) plus defoliation (100\% leaf removal) in litchi reduces endogenous IAA concentration and increased the transcript level of two IAAresponsive genes (LcAUX/IAAl and $L c S A U R 1$ ), one cell wall degrading enzyme gene $(L c P G l)$ and one ethylene biosynthetic gene ( $L c-A C O 1)$, in contrast to the decreasing accumulation of auxin response factor 
(LcARF1) mRNA, with the concomitant increase in fruit drop (Kuang et al., 2012). However a deep knowledge of the molecular events involved in fruit abscission induced by carbohydrate stress is still missing.

It is concluded that the photosynthesizing organs, known as sources, mainly mature leaves, produce photosynthates, mainly carbohydrates, translocated by the sieve tubes of the phloem to non-photosynthetic organs (fruits, roots and tubers) and immature leaves, known as sinks. High, yearly, constant yields and fruit quality require an adequate leaf fruit ratio (number of leaves, certain leaf area per fruit or fresh weight unit). Litchi and mango growers can obtain adequate leaf-fruit-ratios with a reliable canopy and plant management system (like practising girdling, manual removal of winter flushes, and application of paclobutrazol during September-October). Decreasing leaf-fruit ratios increase the photosynthetic efficiency of the leaves but flower induction for the next growth cycle is lower. In contrast, a high leaf-fruit ratio assures a sufficient storage supply, mainly starch, for the following crop, which will inhibit biennial bearing.

\section{References}

Blanke, M.M. 2009. Regulatory mechanisms in source-sink relationships in plants: a review. Acta Hort., 835: 13-20.

Blanke, M.M. and Lenz, F. 1989. Fruit photosynthesis - a review. Plant, Cell Environ., 12: 31-46.

Chang, J.C. and Lin, T.S. 2008. Fruit yield and quality as related to flushes of bearing shoots in litchi. J. Am. Soc. Hort. Sci., 133: 284-289

Chikov, V.I., Abdrakhimov, F.A., Bakirova G.G. and S.N. Batasheva. 2009. The role of sink-source relationships between different organs in regulation of photosynthesis and productivity.
Acta Hort., 835: 87-98

Das, B., Jana, B. R., Dey, P. and Nath, V. 2011. Assimilate Partitioning Behavior in Relation to Fruit Growth in 'Shahi' Litchi. Int. J. Fruit Sci., 11: 88-98.

Fischer, G., Almanza-Marchan, P.J. and Ramirez, F. 2012. Source-sink relationships in fruit species: A review. Revista Colombiana de Ciencias Hort Colas, 6(2): 238-253

Flore, J.A. and A.N. Lakso. 1989. Environmental and physiological regulation of photosynthesis in fruit crops. Hort. Rev., 36: 111-157.

Foyer, Christine H. and Paul, Matthew, J. 2001. Source-Sink Relationships. Encyclopedia of Life Sci., Nature Publishing Group. 1-11pp.

Goffinet, M.C., T.L. Robinson and A.N. Lakso. 1995. A comparison of 'Empire' apple fruit size and anatomy in un-thinned and hand thinned trees. J. Hort. Sci., 70: 375-387.

Goldschmidt, E.E. 1999. Carbohydrate supply as a critical factor for citrus fruit development and productivity. Hort. Sci., 34: 1020-1024.

Goldschmidt, E.E. 2013. The evolution of fruit tree productivity: a review. Economic Botany, 67: 51-62.

Iglesias, D.J., M. Cercós, J.M., ColmeneroFlores, M.A., Naranjo, G., Ríos, E. Carrera, O., Ruiz-Rivero, I. Lliso, R. Morillon, F.R. Tadeo, and M. Talón. 2007. Physiology of citrus fruiting. Braz. J. Plant Physiol., 19(4): 333362.

Jannoyer, M. and Lauri, P.E. 2009. Young flush thinning in mango (cv. cogshall) controls canopy density and production. Acta Hortic., 820: 395402.

Kozlowski, T.T. and S.G. Pallardy. 1997. Physiology of woody trees. $2^{\text {nd }}$ ed. Academic Press, San Diego, CA. 
Kuang, J.F., Wu, J.Y., Zhong, H.Y., Li, C.Q., Chen, J.Y., Lu, W.J. 2012. Carbohydrate stress affecting fruitlet abscission and expression of genes related to auxin signal transduction pathway in litchi. Int. J. Mol. Sci., 13: 16084-16103.

Lauri, P.E., J.J. Kelne, C. Trottier and E. Costes. 2010. Insights into secondary growth in perennial plants: its unequal spatial and temporal dynamics in the apple (Malus domestica) is driven by architectural position and fruit load. Annal Bot., 105: 607-616

Layne, D.R. and Flore, J.A. 1992. Photosynthetic compensation to partial leaf area reduction in sour cherry. $J$. Am. Soc. Hort. Sci., 117: 279-286

Marschner, P. 2012. Marschner's mineral nutrition of higher plants. $3^{\text {th }}$ ed. Elsevier, Oxford, UK.

Monselise, S.P. and Goldschmidt, E.E. 1982. Alternate bearing in fruit trees. Hort. Rev., 4: 128-173.

Myers, S.C. 2003. Training and pruning principles. pp. 339-345. In: Baugher, T.A. and S. Singha (eds.). Concise encyclopedia of temperate tree fruit. Food Products Press, New York, NY

Park, S.J. 2011. Dry weight and carbohydrate distribution in different tree parts as affected by various fruit-loads of young persimmon and their effect on new growth in the next season. Sci. Hort., 130: 732-736.

Protacio, C.M., Quinto J.E., Serrano, E.P., and I.P. Marquez. 2009. Unravelling the Mechanism of Mango Flowering. Acta Hort., 820: 259-270.

Ramirez, Fernando Thomas Lee Davenport, Gerhard Fischer, Julio Cesar Augusto Pinzón, and Christian Ulrichs 2014. Mango trees have no distinct phenology: The case of mangoes in the tropics. Sci. Hort., 168: 258-266.

Robbertse, H., Fivaz, J. and Menzel, Chris 1995. A Re-evaluation of Tree Model, Inflorescence Morphology, and Sex Ratio in Lychee (Litchi chinensis Sonn.), J. Amer. Soc. Hort. Sci., 120(6): 914-920.

Rosenthal, J.P. and Kotanen, P.M. 1994. Terrestrial plant tolerance to herbivory. Trends in Eco. Evo., 9: $145-48$.

Taiz, F.M. Rodriguez. L. and E. Zeiger. 2006. Plant Physiology. $4^{\text {th }}$ ed. Sinauer Associates, Sunderland, MA.

Yuan, R.C., and Huang, H.B. 1988. Litchi fruit abscission: its patterns, effect of shading and relation to endogenous abscisic acid. Sci. Hort., 36: 281-292.

\section{How to cite this article:}

Sanjay Kumar Singh, Vishal Nath, E.S. Marboh and Swati Sharma. 2017. Source-Sink Relationship in Litchi verses Mango: A Concept. Int.J.Curr.Microbiol.App.Sci. 6(3): 500-509. doi: https://doi.org/10.20546/ijcmas.2017.603.058 